University of Northern lowa

UNI ScholarWorks

Rod Library Faculty Publications

Rod Library

$5-3-2008$

\title{
Modeling Scholarly Inquiry: One Article at a Time
}

Anne Marie H. Gruber

University of Northern lowa

Mary Anne Knefel

See next page for additional authors

Let us know how access to this document benefits you

Copyright (C) 2008 Anne Marie H. Gruber, Mary Ann Knefel, Jessica Schreyer, and Paul Waelchli Follow this and additional works at: https://scholarworks.uni.edu/lib_facpub

Part of the Library and Information Science Commons

\section{Recommended Citation}

Gruber, Anne Marie H.; Knefel, Mary Anne; Schreyer, Jessica; and Waelchli, Paul, "Modeling Scholarly Inquiry: One Article at a Time" (2008). Rod Library Faculty Publications. 3.

https://scholarworks.uni.edu/lib_facpub/3

This Article is brought to you for free and open access by the Rod Library at UNI ScholarWorks. It has been accepted for inclusion in Rod Library Faculty Publications by an authorized administrator of UNI ScholarWorks. For more information, please contact scholarworks@uni.edu. 


\section{Authors}

Anne Marie H. Gruber, Mary Anne Knefel, Jessica Schreyer, and Paul Waelchli 


\section{Student research questions}

- Why is the media racist?

- When local television news programs report violent crime, do they reinforce negative stereotypes of AfricanAmericans? 


\section{Student research questions}

- Why are gamers violent?

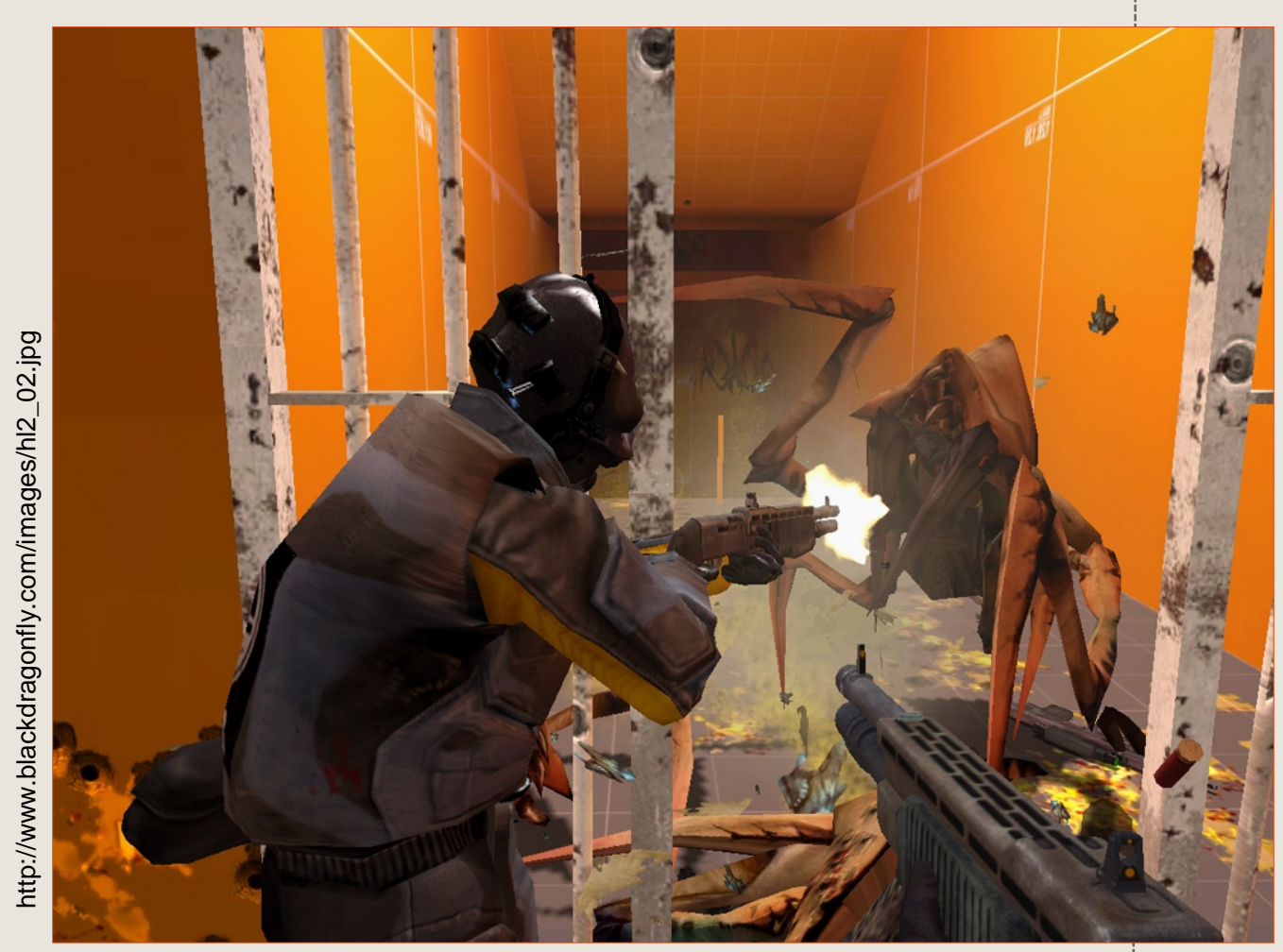

- Does playing violent video games increase aggression in college students? 


\section{Student-generated thesis statement}

- Evidence suggests that playing violent video games may increase aggression in college students through cognitive, emotive, and behavioral reactions in controlled situations. 


\section{Modeling Scholarly Inquiry: One Article at a Time}

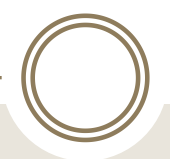

\section{LOEX : 2008 MAY 3}

\section{LIBRA RIA NS}

PAUL WAELCHLI ANNE MARIE GRUBER MARY ANNE KNEFEL

WRITING CENTER DIRECTOR/ ENGLISH FACULTY

J ESSICA SCHREYER 


\section{How does it happen?}

- Required English 102 course, Composition and Rhetoric II

- Process-based, collaborative unit

- Common research question and 3 common articles discussed in class (all class/ small groups)

- Deliverable: Individual papers proving common thesis 


\section{What needs are addressed?}

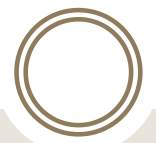

- Students underprepared for research/writing in subsequent required course

- RES104 Introduction to Research Writing

- Tasks:

○ Narrowing topics

○ Researching focused questions

o 5-page thesis papers 


\section{What opportunities prompted the unit?}

- Com 101 (Basic Speech): common assignments begun in 2001/ 02

- Wendt Character Initiative 


\section{What are the outcomes?}

- Students will:

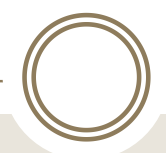

o Identify a valid thesis statement

o Identify credible sources

o Read journal articles and identify evidence that supports, refutes, or modifies the research question

o Write a short thesis-driven paper based on credible sources

o Cite and use sources correctly 


\section{Outcomes Frameworks}

- ACRL Standards \& Writing Program Administrators Outcomes

\begin{tabular}{|l|l|l|}
\hline \multicolumn{1}{|c|}{ Unit Outcomes } & \multicolumn{1}{|c|}{ ACRL Outcomes } & \multicolumn{1}{|c|}{ WPA Outcomes } \\
\hline & $\begin{array}{l}\text { 3.1a: Reads the text and selects main ideas } \\
\text { 3.1b: Restates textual concepts in his/her own } \\
\text { words and selects data accurately } \\
\text { 3.1c: Identifies verbatim material that can be } \\
\text { then appropriately quoted }\end{array}$ & $\begin{array}{l}\text { Understands a writing } \\
\text { assignment as a series of } \\
\text { tasks, including finding, } \\
\text { evaluating, analyzing, and } \\
\text { synthesizing appropriate } \\
\text { from 3 journal articles to } \\
\text { support or refute a } \\
\text { thesis }\end{array}$ \\
$\begin{array}{l}\text { 3.3a: Recognizes interrelationships among } \\
\text { concepts and combines them into potentially } \\
\text { useful primary statements with supporting } \\
\text { evidence } \\
\text { p.4b: Uses consciously selected criteria to } \\
\text { determine whether the information } \\
\text { contradicts or verifies information used from } \\
\text { other sources }\end{array}$ & \\
\hline
\end{tabular}




\section{Why collaborate?}

- 'Writing centers and libraries have been living parallel lives, confronting many of the same problems and working out similar solutions, each in their own institutional contexts" (Elmborg and Hook, 2005).

- Both teach holistic, integrated processes.

- Research \& writing are connected and cyclical. 


\section{How does this foster student growth?}

- Process - driven decisions requiring supporting evidence \& value judgments (Norris, 1989)

- Call for colleges to teach students how to "offer and demand evidence. . for their moral and political positions" (Ann Colby et al., 2003)

- Students have trouble analyzing complex questions for which there is no single answer 


\section{How does the unit work?}

- 8 class days

- Librarians involved on Days 1-5

- Tutors involved days 2-5 


\section{Day 1}

- Last 15-20 min. of class

- Librarian introduces course management system access and topic

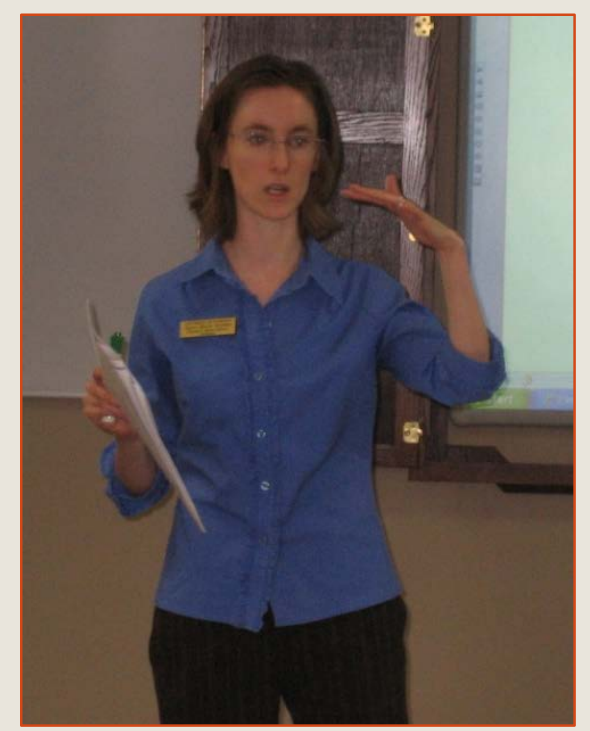




\section{Day 2}

- News articles or websites to introduce topic

- Begin modeling reading 1 scholarly article through in-depth discussion \& annotation

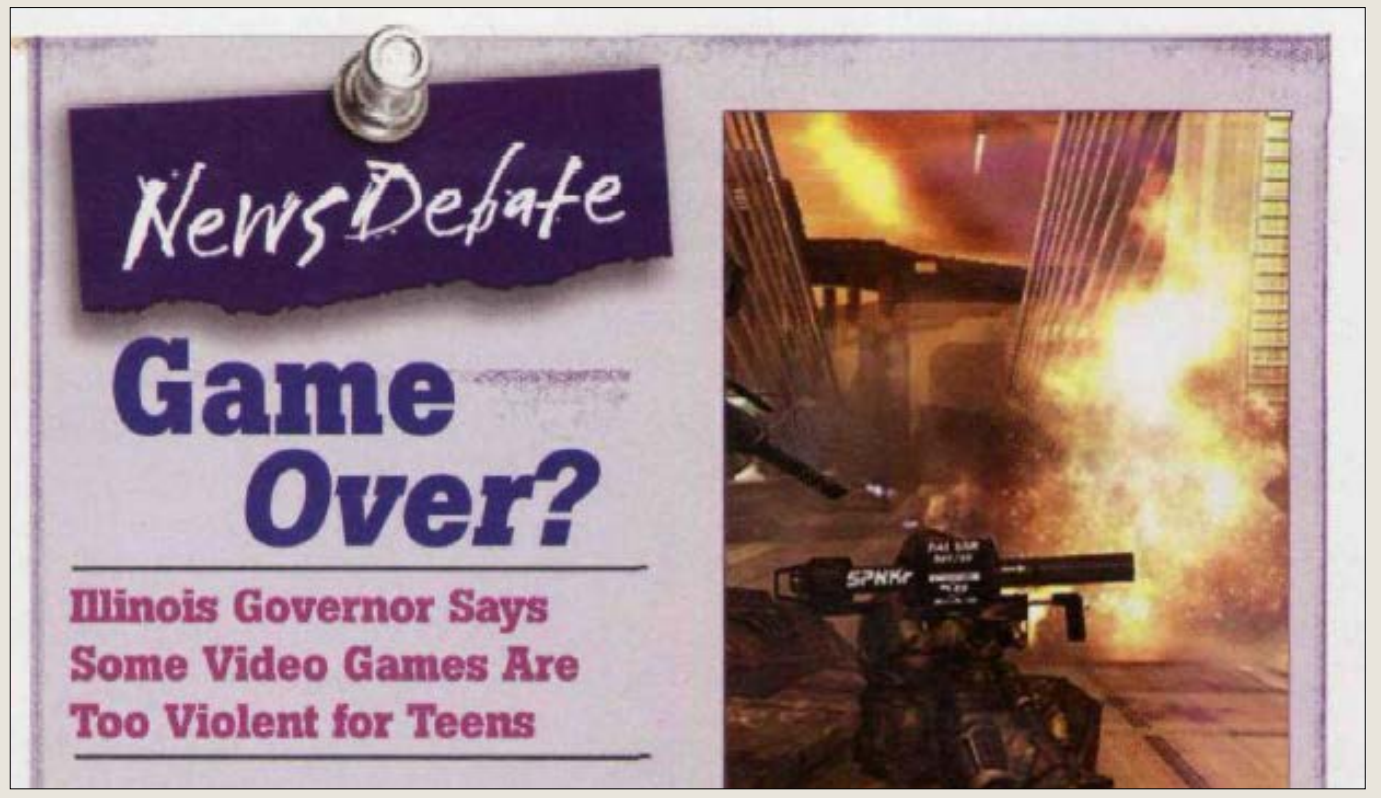




\title{
Sample class article
}

Journal of Experimental Social Psychology 38, 283-290 (2002)

doi:10.1006/jesp.2001.1502, available online at http://www.idealibrary.com on IDE

\section{Effects of Violent Video Games on Aggressive Behavior: Potential Sex Differences}

\author{
Bruce D. Bartholow \\ University of Missouri-Columbia
}

and

Craig A. Anderson

Iowa State University

Received July 31, 2000; revised August 15, 2001; accepted August 30, 2001; published online December 3, 2001

Evidence of the effects of playing violent video games on subsequent aggression has been mixed. This study examined how playing a violent video game affected levels of aggression displayed in a laboratory. A total of 43 undergraduate students ( 22 men and 21 women) were randomly assigned to play either a violent (Mortal Kombat) or nonviolent (PGA Toumament Golf) video game for 10 $\min$. Then they competed with a confederate in a reaction time task that allowed for provocation and retaliation. Punishment levels set by participants for their opponents served as the measure of aggression. The results confirmed our hypothesis that playing the violent game would result in more aggression than would playing the nonviolent game. In addition, a Game $\times$ Sex interaction showed that this effect was larger for men than for women. Findings arc discussed in light of potential differences in aggressive style between men and women. 0 2001 Elsevier Science (USA)

Key Words: aggressive behavior; video games; sex differences; provocation; punishment. 


\section{Day 3}

()

- Conclude discussing first scholarly article

- Peer collaboration: Groups are assigned

- Facilitators prepare students to read another article by examining section headings

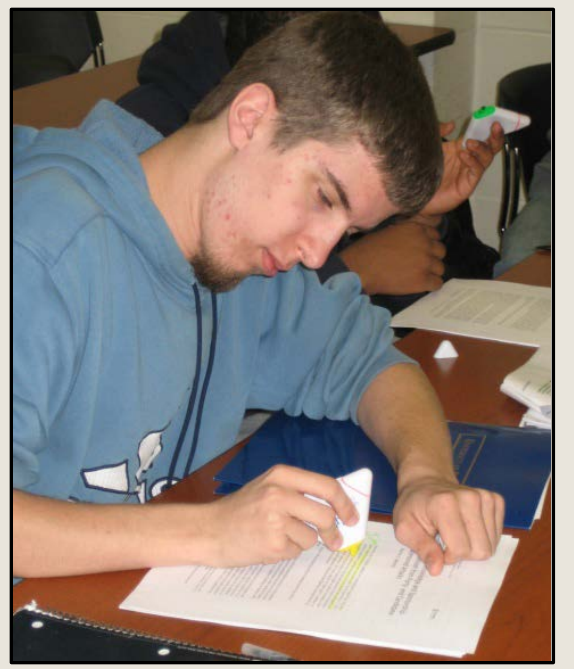




\section{Day 4}

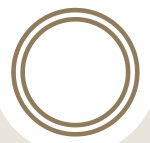

- Small groups meet with facilitators

o Groups of 4-5 students

- Each group discusses another article in detail

- Groups determine evidence relevant to research question

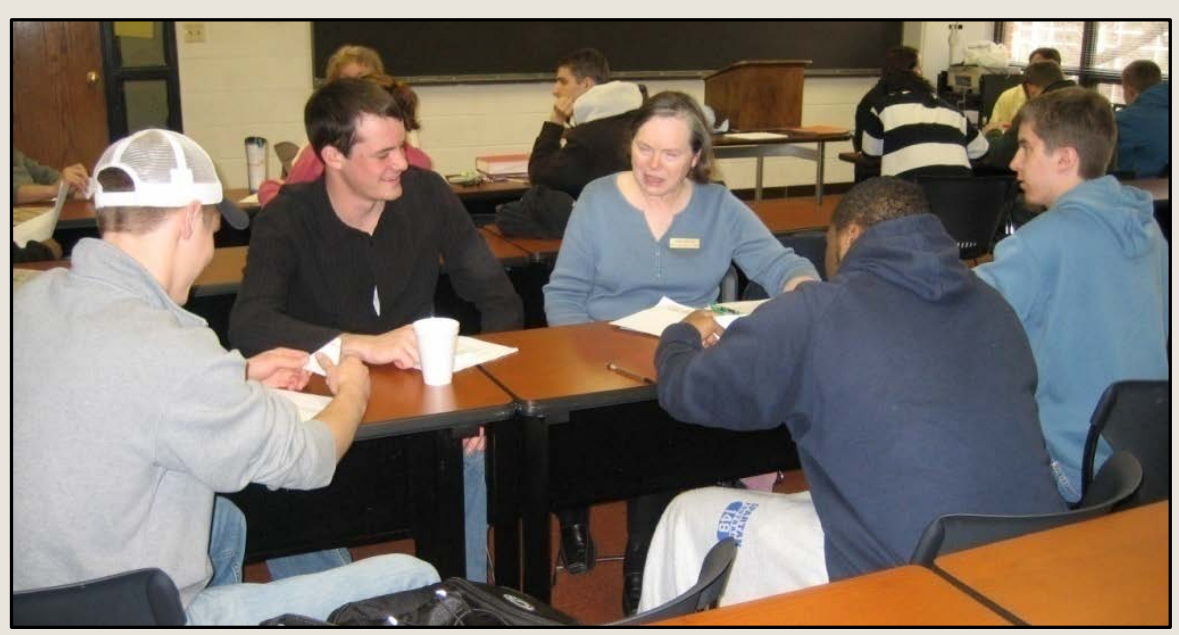




\section{Day 5}

- Small groups present relevant evidence
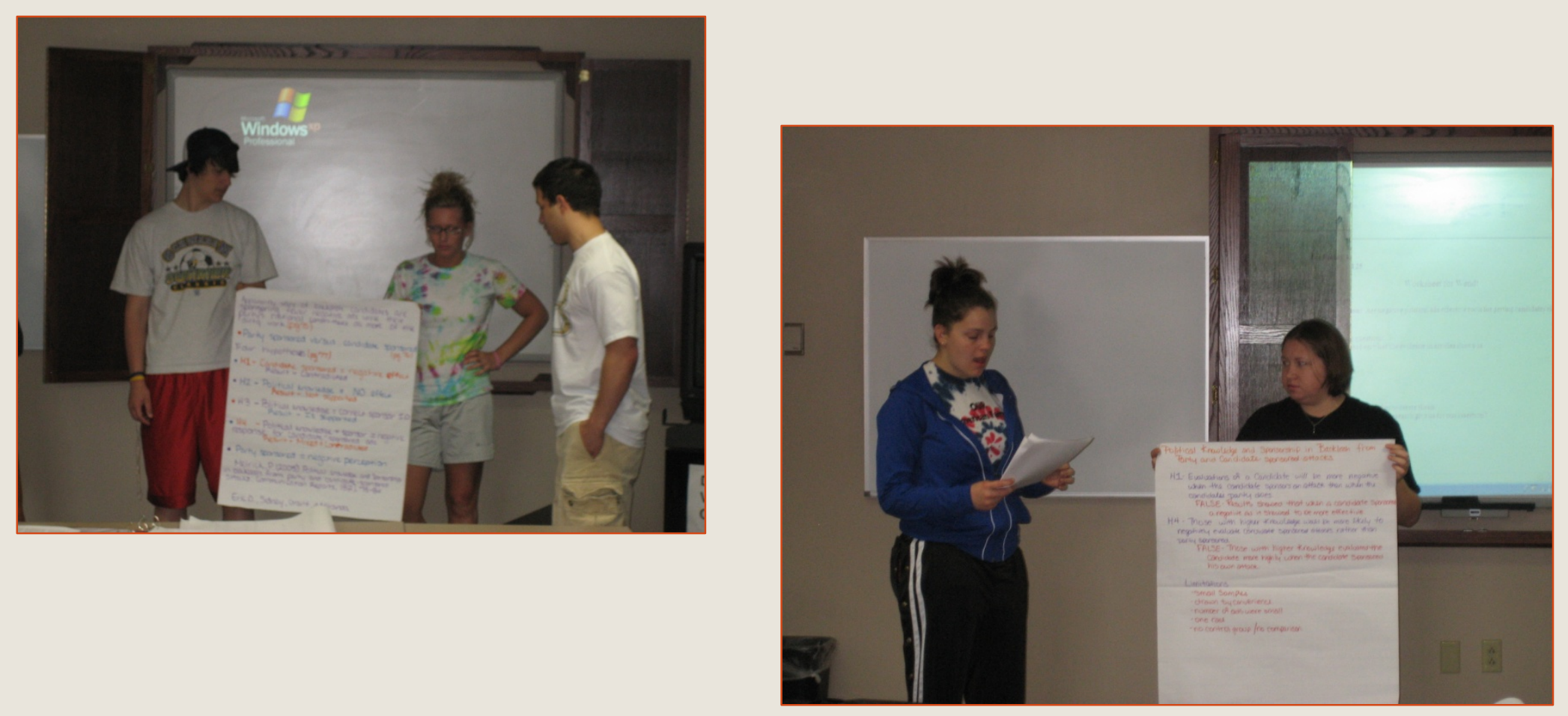

- Class determines common thesis statement 


\section{Day 6}

- Instructor leads class in creating outline

- Review of quoting/ paraphrasing/ summarizing

- Review of citation style 


\section{Day 7}

- First draft due

- Includes references

- Peer-review in class
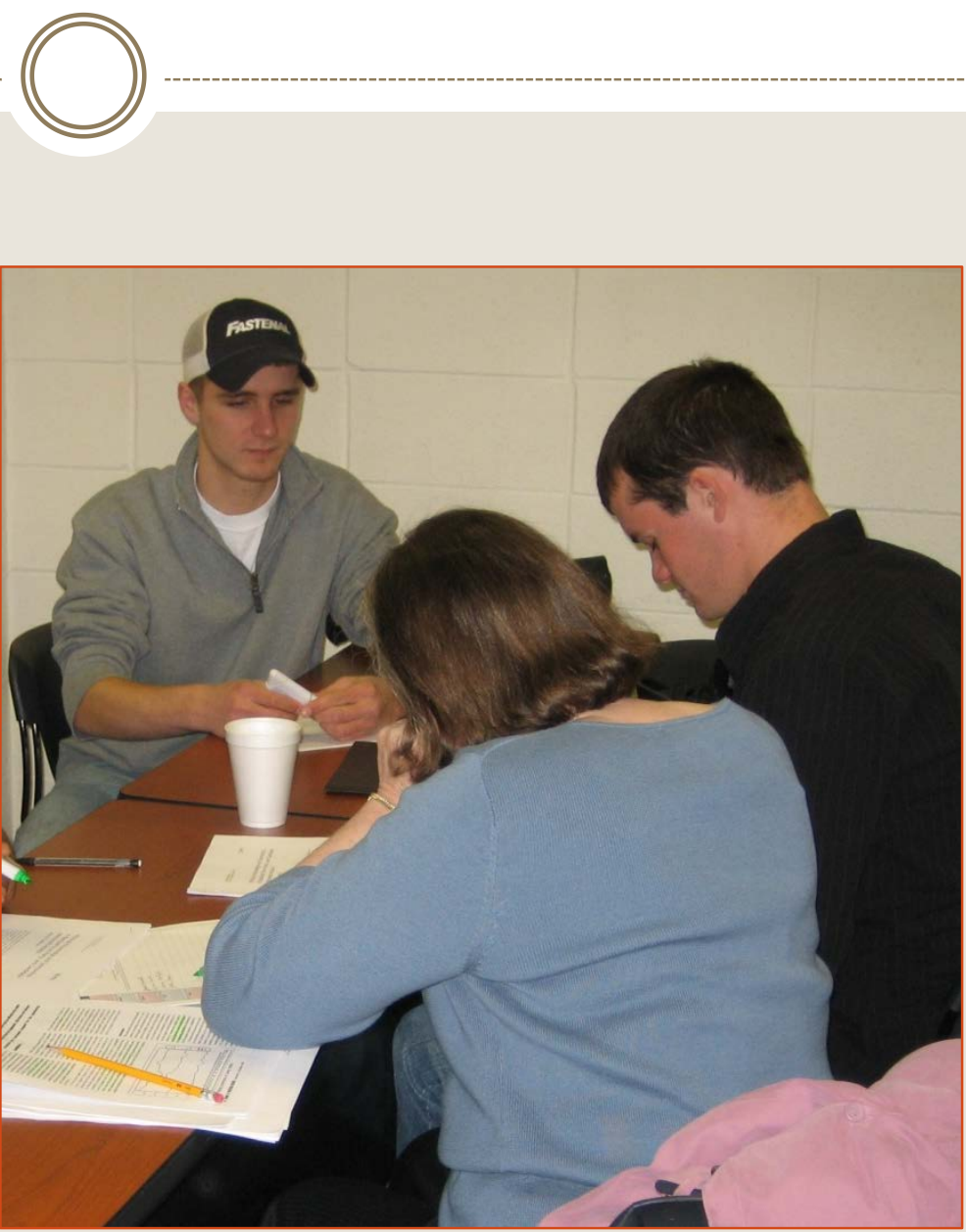


\section{Day 8}

- Final paper due

- Portfolio includes:
o Annotated articles
o First draft with references
o Peer-review forms
o Additional drafts
o Final draft with references 


\section{Isn't this too much hand-holding?}

- Reading and synthesizing is difficult for students

- Models scholarly inquiry as collaborative \& reverses misconception that research writing is isolated

- Changes power relationships

- Introduces students to librarians and writing tutors 


\section{Don't they all just plagiarize?}

- Emphasis on process

- Accountability throughout

- Prevents future plagiarism 


\section{Who is involved \& what are their responsibilities?}

-

- Faculty

- Librarians

- Writing Center Director

- Writing Tutors

- Students

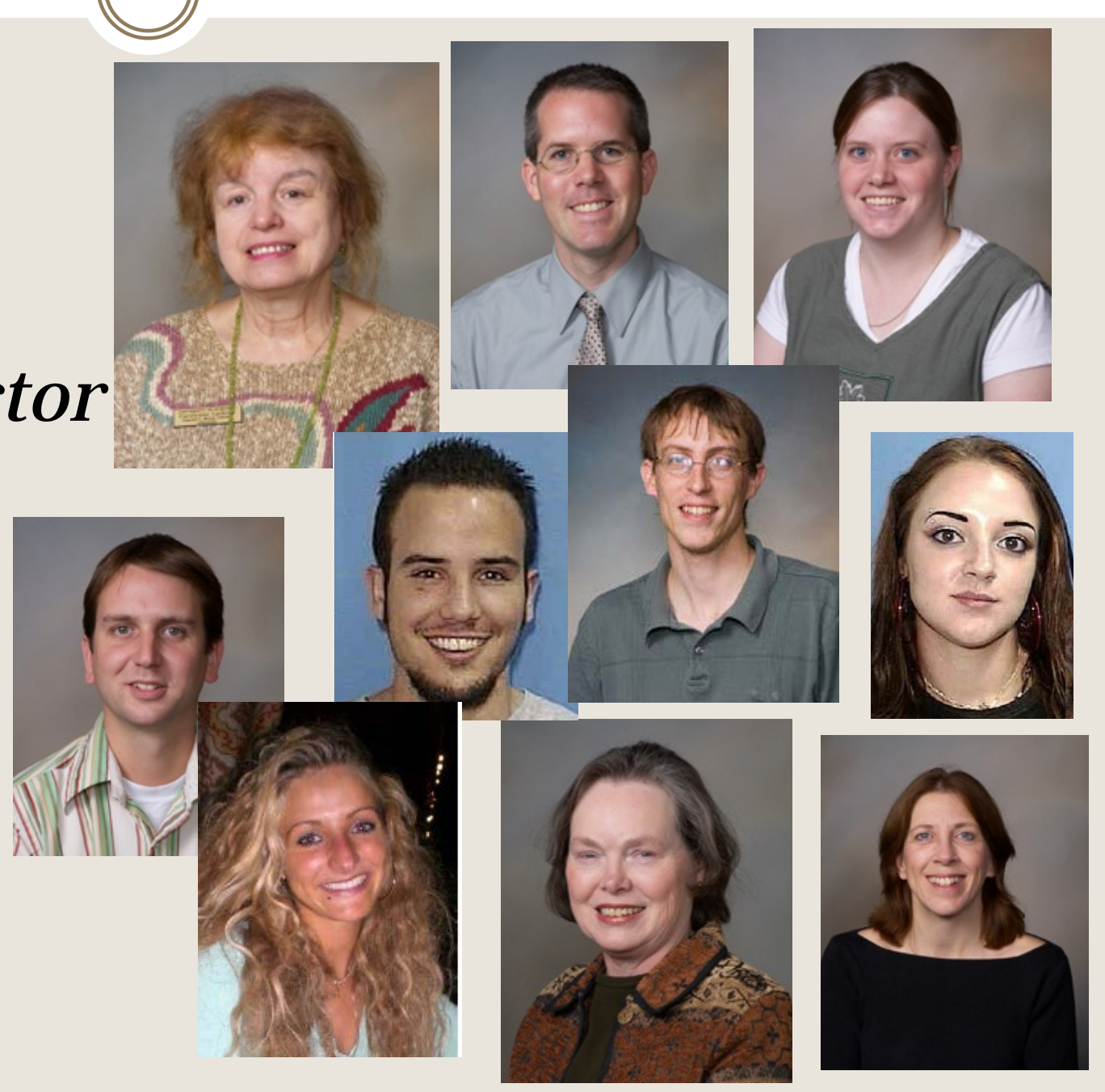




\section{English Faculty}

- Create \& share assignment sheets, rubrics, and ideas

- Build on writing concepts practiced throughout course

- Facilitate one group

- Final assessment: grading

- Available for students outside of class 


\section{Librarians}

- Choose topics/articles

- Lead initial topic \& article discussion

- Facilitate one small group

- Available outside of class for students

- Schedule unit with instructors, provide materials:

o Brochure

○ Faculty presentations 


\section{Writing Center Director \& Tutors}

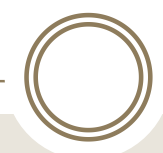

- Schedules peer \& professional tutors for unit

- Trains \& prepares tutors

- Available outside of class in Writing Center

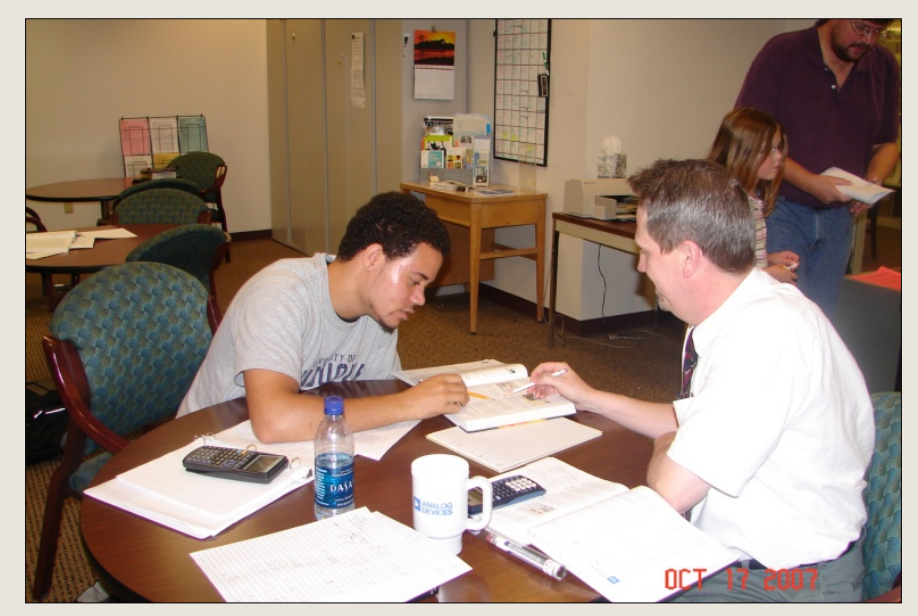

- Facilitates groups 


\section{ENG102 Students}

- Prepare by reading each day's article

- Actively participate in class and small group discussions

- Write individual paper

- Meet with Writing Center tutor if desired 


\section{How are topics \& articles chosen?}

- Provocative, timely, ethical topics likely to be of interest to students

- Article criteria:

○ Length (ideally 6-12 pages)

○ Accessibility

o Importance in field

○ Varying authors

○ Fit with research focus

- Clear thesis

o Currency 


\section{How is the unit assessed?}

- Part of overall IL assessment plan

- Pilot written assessment Fall 2007

- Some questions from baseline assessment (TRAILS)

○ 83.3\% could ID appropriate research paper topic (+7.6\%)

o $62.5 \%$ could ID resource type from citation $(+24.4 \%)$

○ $75.0 \%$ could ID example of proper paraphrasing ( $+38.2 \%)$

○ $29.2 \%$ could ID example of bias (-2.2\%) 


\section{Overall assessment}

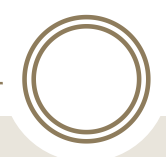

- Grades/ quality of student work

- Process more than product

- Success in RES104 Introduction to Research Writing

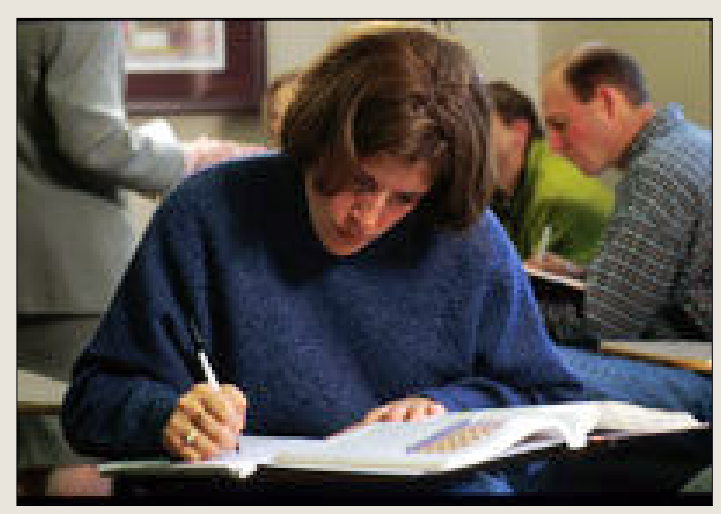




\section{How has the collaboration worked?}

- Different roles but common goals for students

- English faculty, tutors and librarians meet separately as needed

○ J essica is liaison between groups

o Anne Marie meets with new instructors individually

- Has increased opportunities for additional collaboration 


\section{What are the librarians' perceptions?}

()

- Finding right topic \& articles can be time-consuming

- Scheduling and collaboration takes time

o ENG102 accounted for 86 of 375 IL sessions in 2006-2007

- Great interactions with students 


\section{What are the faculty members' perceptions?}

- Some apprehension at first about process \& time commitment

- Some requested additional librarian involvement

- Many modified timeline

"I believe the students were energized by the discussions led by the librarians in the small groups. I, on the other hand, need a bit more work pulling information rather than pushing it." 


\section{What are the Writing Center staff's perceptions?}

- Scheduling \& training tutors takes time and resources

- Additional visibility for Writing Center 


\section{Tutors' perceptions}

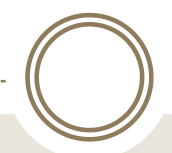

- More time for positive interactions with students

- Comfort level increases the more they participate

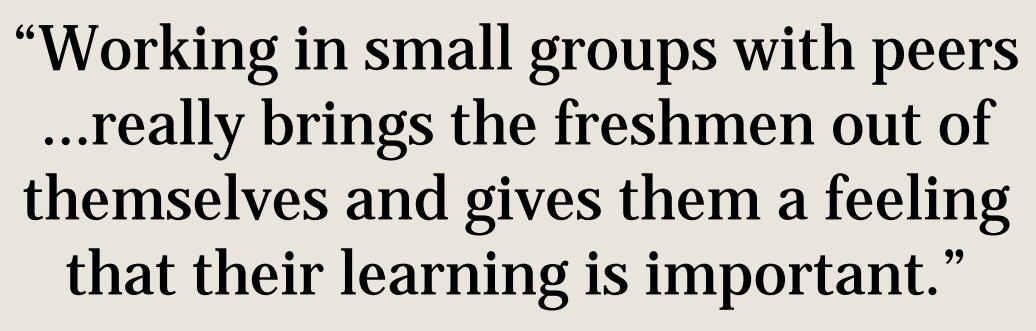

"It also made me realize that what I had learned was actually being used..." 


\section{What are the students' perceptions?}

- Topics won't engage every student

- Some students find it difficult to detach from personal experience

- Want to advocate opinions \& unsure how to use evidence

- Most enjoyed experience \& felt successful

"Best part of the entire ENG semester"

"I feel like I am more prepared for the research writing class that I am taking next semester."

"That was the closest I have ever worked with a teacher." 


\section{What's next?}

- Increasing student accountability through small writing assignments throughout unit

- More opportunities to collaborate with faculty and between Writing Center \& librarians

- Reinforce concepts in upper-level major courses

- Collaborate with Education Department for peer group leaders 


\section{What did you learn?}

- Peer collaborative learning is central to research writing and critical thinking.

- Ethical questions lead to critical thinking.

- Librarians and writing center professionals are wellpositioned to take the lead in teaching critical thinking. 


\section{More information}

- Knefel, M.A., Waelchli, P., \& Gruber, A.M.H. (2008). Modeling academic inquiry: One article at a time. College and Undergraduate Libraries. In press. 


\section{Suggested resources}

- Association of College \& Research Libraries. Information Literacy Competency Standards for Higher Education. Available from http://www.ala.org/ala/ acrl/acrlstandards/standards.pdf

- Boyer, Ernest L. 1987. College: The undergraduate experience in America. New York: Harper \& Row.

- Colby, Anne, Thomas Ehrlich, Elizabeth Beaumont, and Jason Stephens. 2003. Educating citizens: Preparing America's undergraduates for lives of moral and civic responsibility. San Francisco: J ossey-Bass.

- Council of Writing Program Administrators. 2000. WPA Outcomes Statement for First-Year Composition. Available from http:// www.wpacouncil.org/ positions/ outcomes.html

- Elmborg, J ames. K, and Sheril Hook. 2005. Centers for Learning: Writing Centers and Libraries in Collaboration. Chicago: Association of College and Research Libraries. 


\section{Suggested sources (cont.)}

- Higgins, Lorraine. 1993. Reading to argue: Helping students transform source text. In Hearing ourselves think: Cognitive research in the college writing classroom, ed. Ann M. Penrose and Barbara M. Sitko, 70-101. New York: Oxford University Press.

- Hughes, William. 2000. Critical thinking: An introduction to basic skills. 3rd ed. Peterborough, Ont.: Broadview Press.

- King, Patricia M., and Karen S. Kitchener. 1994. Developing reflectivejudgment: Understanding and promoting intellectual growth and critical thinking in adolescents and adults. San Francisco: J ossey-Bass.

- Norris, Stephen P., and Ennis Robert H. 1989. Evaluating critical thinking. Pacific Grove, CA: Midwest Publications.

- Vygotsky, Lev S. 1978. Mind in society: The development of higher psychological processes. Ed. by Michael Cole. Cambridge, MA: Harvard University Press. 